\title{
Erratum to: Validation of verbal autopsy: determination of cause of deaths in Malaysia 2013
}

Shubash Shander Ganapathy ${ }^{1 *}$, Khoo Yi Yi ${ }^{2}$, Mohd Azahadi Omar ${ }^{1}$, Mohamad Fuad Mohamad Anuar ${ }^{1}$, Chandrika Jeevananthan ${ }^{1}$ and Chalapati Rao ${ }^{3}$

\section{Erratum}

After publication of the article [1], it has been brought to our attention that some of the authors had their names presented incorrectly. Author 2 should be "Khoo Yi Yi", author 3 should be "Mohd Azahadi Omar" and author 4 should be "Mohamad Fuad Mohamad Anuar". These corrections have been made in the original version of the article.

\section{Author details}

${ }^{1}$ Institut Kesihatan Umum (Institute of Public Health), Ministry of Health Malaysia, Jalan Bangsar, 50590 Kuala Lumpur, Malaysia. ²Department of Social and Preventive Medicine, University of Malaya, Kuala Lumpur, Malaysia.

${ }^{3}$ Department of Global Health, Research School of Population Health,

Australian National University, Canberra, Australia.

Received: 14 August 2017 Accepted: 17 August 2017

Published online: 31 August 2017

\section{Reference}

1. Ganapathy S, Khoo Y, Azahadi M, Fuad M, Jeevananthan C, Rao C. Validation of verbal autopsy: determination of cause of deaths in Malaysia 2013. BMC Public Health. 2017;17:1. doi:https://doi.org/10.1186/s12889-017-4668-y.

\footnotetext{
* Correspondence: shubashshander@gmail.com

${ }^{1}$ Institut Kesihatan Umum (Institute of Public Health), Ministry of Health

Malaysia, Jalan Bangsar, 50590 Kuala Lumpur, Malaysia
} 